\title{
黑龙江省义务教育均等化研究
}

\author{
高红丽
}

哈尔滨商业大学

DOI:10.32629/er.v2i12.2244

[摘 要] 有效推进义务教育均等化的发展,是我国基础教育发展的一个新的战略选择。在对黑龙江省义务教育均等化水平进行调查研究后,结 果表明: 黑龙江省全省的义务教育存在着很多不均等, 存在义务教育发展区域间失衡、义务教育发展城乡间失衡、义务教育发展同一地区校际 间失衡的问题。解决方法是增加经济欠发达地区义务教育的财政投入、加强师资队伍建设,形成合理的人才流动机制、健全相关的法律法规, 保障义务教育的均衡发展, 以促进全省义务教育均等化的均衡发展,努力形成惠及全民的公平教育。

[关键词] 黑龙江省; 义务教育; 均等化水平; 实证研究

义务教育均等化指的是每个人享受的义务教育大致相同, 而不是不顾 经济发展水平的差异, 硬性地搞同步发展和平均发展。因为义务教育的供 给能力和地方经济发展水平息息相关, 所以地区经济发展水平存在差异, 义务教育的发展就也同样存在差异。

\section{1 黑龙江省义务教育均等发展成绩检视}

近年来, 黑龙江省在和进一步推进公共服务均等化、特别是公共教育 均等化的背景下, 于 2007 年推出了《黑龙江省教育改革和发展规划纲要 (2009 2020)》, 明确了实现义务教育均等化的分阶段目标, 并于2011年与 教育部签署了义务教育均衡发展备忘录, 进一步明确了教育部和黑龙江省 人民政府共同推进义务教育均衡发展的责任。

\section{2 黑龙江省义务教育均等化存在的问题}

黑龙江省虽然在推进义务教育均衡发展的过程中取得了一些成绩, 但 由于受到经济发展水平、政策、教育投入等因素的影响, 各区域义务教育 的均衡发展也存在着一些问题, 主要体现在以下三个方面:

2.1 义务教育发展区域间失衡。黑龙江省义务教育发展区域间失衡, 主要表现在经济发达的中部地区哈尔滨市、齐齐哈尔市、大庆市与经济欠 发达的南部地区伊春林区、鹤岗煤矿和北部大兴安岭塔河林区的差距上。

首先, 教育投入与各个地区的经济发展状况有着密切的关系。从黑龙 江省各地市GDP排名数据可以看出, 从GDP排名上可见, 黑龙江省各地区域 之间的经济发展很不平衡, 哈尔滨、齐齐哈尔、大庆地区占有绝对的优势, 其他地区尤其是伊春林区和鹤岗煤矿、大兴安岭塔河林区地区的经济发展 相对落后, 而某一地区经济的发展水平直接影响着其对教育的投入。

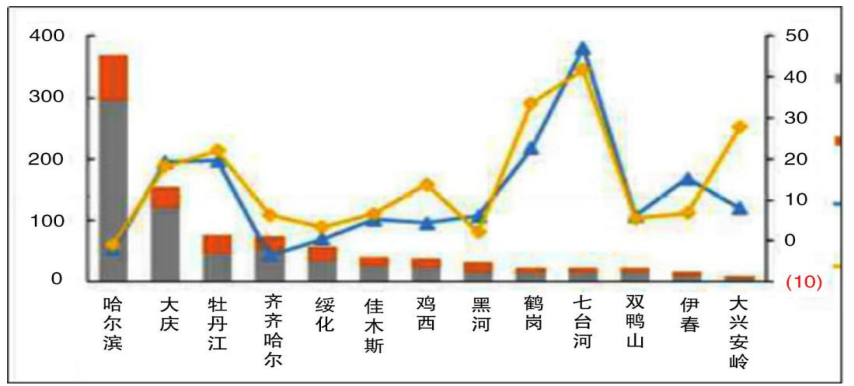

图2 2018年黑龙江省各地市GDP排名数据

其次, 教育经费投入占财政支出的比例可以反映出一个国家或地区对 教育的重视程度。图2是黑龙江省各个区域的地方财政一般预算收入对比 情况, 由此可以间接得出各地区财政收入悬殊是导致其对义务教育的投入 差距的主要原因。哈尔滨和大庆地区的地方财政一般预算收入明显高于其 他三个区域, 以中部地区的哈尔滨市为例, 《关于哈尔滨市2018年预算执行 情况和2019年预算草案的报告》显示, 2018年哈尔滨市一般预算总支出为
1192. 4 亿元, 教育支出所占比例为 $6.07 \%$, 约合人民币 90.6 亿元, 而这个数 目几乎占南部和北部地区财政一般预算收入的一半。

由以上的数据分析可以看出, 南部和北部地区因义务教育经费短缺, 致使这些地区义务教育的发展举步维艰。

中部地区普通小学及初中教师具有本科以上学历者已达 $90 \%$ 以上, 具有 研究生学历的教师也占有一定的比例, 而南部一些城市具有本科学历的教 师仅占 $40 \%$ 左右。北部林区教师的学历层次则更低。教师队伍老龄化现象严 重, 学历悬殊是导致黑龙江省义务教育发展区域间失衡的重要原因之一。

在中部地区的哈尔滨市、齐齐哈尔市和大庆市, 学校校园环境优美舒 适, 教学和生活设施完善, 各种文体设施场所等一应俱全。中小学计算机等 设备的配备量已接近发达国家的标准。以 “每名学生拥有计算机台数” 为 衡量指标, 以哈尔滨市为例, 全市中小学的生机比为 $8: 1$, 个别学校甚至达 到 $5: 1$, 而南部和北部个别县城小学的生机比为 $200: 1$ 。义务教育规范化学 校覆盖率也存在明显的差异。截至2018年, 黑龙江省中部各市义务教育规 范化学校覆盖率已达 $80 \%$ 以上, 而北部地区的大兴安岭塔河县林区义务教 育规范化学校的覆盖率仅为 $32.21 \%$ 。

2.2 义务教育发展城乡间失衡。受我国城乡二元结构的影响, 在义务教育 发展阶段, 黑龙江省城市与农村的中小学在教育投入、师资力量、办学水平 等方面都存在较大的差距。哈尔滨、齐齐哈尔、大庆地区一些城市投入巨额 资金建设 “示范性学校” 或 “标志性学校”, 而在南部北部的一些乡村学校, 有不少孩子仍在没有窗户的简陃教室里上课。哈尔滨、大庆地区有的城市学 校建有超标准运动场、高级网球场、多功能健身房等, 而不少南北地区乡村 学校的学生却买不起必需的文具, 教师缺少必要的教学材料。下面以北部大 兴安岭地区塔河县为例, 分析黑龙江省义务教育发展城乡间失衡问题。

生师比是评价师资水平的一个重要指标, 它在一定程度上反映了学校 软件条件的好坏, 并直接影响着学校教育教学质量的高低。从调查数据可 以看出, 黑龙江省义务教育城乡之间存在着较大的差距, 农村学校比城市 学校的生师比存在明显差距, 其中小学阶段尤为明显, 这说明了一个问题, 城市学校的师资比农村学校的师资要强得多。虽然这只是一个地方的数据, 但却是整个黑龙江省义务教育城乡失衡的现实折射。

教学设施方面, 黑龙江省发达城市学校基本实现了多媒体教学, 而许 多农村中小学教学仪器陈旧, 上世纪六七十年代的设备还在使用, 难以满 足义务教育发展的要求, 有的农村学校即使有计算机, 也没有网络, 或网络 运行、开发和管理不到位, 使得城市与农村的义务教育差距进一步扩大。

2.3 义务教育发展同一地区校际间失衡。黑龙江省义务教育失衡现象不 仅存在于区域之间、城乡之间, 还存在于同一地区的校际之间。同一地区, 有省市一级学校与二级学校之分, 有重点学校与普通学校之分, 有公办学校 


\title{
思想政治教育功能与文化产业功能耦合关系研究
}

\author{
秦盈艺田云刚 \\ 山西农业大学 马克思主义学院
}

DOI:10.32629/er.v2i12.2265

\begin{abstract}
[摘要] 文化产业是21世纪发展的“朝阳产业”, 文化产业区别于其它产业形式同时蕴含着经济属性与文化属性。就其文化特性来看,文化产 品由人生产, 因此不可避免就会伴随着内容生产者的某些观念、规则与感受, 所以其思想观念、政治观点以及道德规范在一定程度上都会不自觉 地物化在产品中, 而文化产业以及文化产品在发挥自己经济功能的同时也发挥着意识形态功能,如教育功能、传播功能以及激励功能等特性,这 与思想政治教育功能有着密切联系。因此, 从文化意识形态出发, 在不同学科中汲取二者共性加以研究, 分析文化产业与思想政治教育功能中的 耦合关系。
\end{abstract}

[关键词] 思想政治教育功能; 文化产业功能; 耦合关系

思想政治教育功能与文化产业中所蕴含的意识形态功能存在诸多关 联。思想政治教育对于文化产业的前进方向引领作用。文化产业的生产、 加工以及消费过程需要思想政治教育进行正确引导。另一方面文化产业的 发展可以促进思想政治教育中个体性与社会性功能发挥。文化产业中所蕴 含的传播功能以及育人功能与思想政治教育功能中对社会群体的教化、激 励、促进等作用使二者能够发挥正关联的作用, 最终能够达到凝聚人心的 作用。

\section{1 思想政治教育的功能}

思想政治教育从功能性上来说主要分为思想政治教育个体性功能和思 想政治教育的社会性功能, 首先思想政治教育有助于个体功能的发挥, 其次 思想政治教育的社会性功能通过经济功能、政治功能以及文化功能所体现。

思想政治教育的经济功能是指思想政治教育通过调动教育对象的积极 性, 促使其主动参与经济活动以促进经济又好又快发展的作用。冊庸置疑一 个和谐稳定社会的构建离不开经济的发展。经济与上层建筑相互联系, 因而 物质生产也必须遵循正确导向, 思想政治教育对于经济建设起到正确的方
向保证作用, 从根源上确保经济建设的前进方向不会偏离社会主义道路。另 一方面思想政治教育对于积极推动社会生产起到重要作用。如马克思所述, “各种经济时代的区别, 不在于生产什么, 而在于怎样生产、用什么资料生 产”。在生产力结构中包含着劳动资料、劳动对象以及劳动者三个基本要素, 而劳动者处于最活跃因素。而从思想政治教育维度来看, 思想政治教育者一 定的观念传输与价值体系的构建对于思想政治教育对象产生影响, 思想政 治教育者通过提高其思想政治素养进一步推动其参与社会生产的积极性。

思想政治教育的政治功能是指思想政治教育通过培养具有良好思想政 治教育素质的受教育者以推动政治发展的作用。思想政治教育通过传导主 导意识形态、调节社会精神生产, 传播主导政治意识、引导受教育者的政治 行为, 沟通社会信息, 确保社会的有机联系来发挥其政治沟通, 促进社会政 治的稳定和发展。文化产业的发展以及思想政治教育功能发挥其根本目的 都是为了推动社会主义精神文明建设, 凝聚社会主义核心价值观, 而文化产 业为思想政治教育功能的发挥搭建了物质桥梁, 形成了思想政治的一种特 殊载体。同时, 思想政治教育又决定了文化产业发展的性质和方向, 保证文
与民办学校之分造成生源质量不均衡, 条件好的学校可以在学生中千挑 万选, 而条件差的学校还得为争取生源而奔波。师资力量也不均衡, “学 科带头人”、“骨干教师”、“高学历人才” 等优秀教师资源集中在少数优 质学校里, 而学历层次较低、业务水平相对较低的教师, 往往分布在薄弱 学校和边远学校。薄弱学校的存在, 使公民无法平等享受优质的教育资 源, 导致了中小学 “择校热” 现象的产生, 致使义务教育的均衡发展受到 了严重的影响。

\section{3 黑龙江省义务教育均衡发展的对策}

3. 1增加经济欠佳地区义务教育的财政投入。教育的发展离不开财政 的支撑。自2010年以来, 黑龙江省将义务教育经费全面纳入公共财政范围, 建立了省、市、县分项目、按比例分担义务教育经费的保障机制。但由于 各地经济发展水平的不均衡, 导致对义务教育的财政投入差距悬殊, 特别 是经济欠发达地区的义务教育投入相对较少。为了扭转义务教育投入不足 的局面, 地方政府应进一步增加财政投入力度。

3. 2 加强师资队伍建设, 形成合理的人才流动机制。加强师资队伍建设。 应强化管理机制, 制订合理的绩效工资方案, 真正体现 “多劳多得、优绩优 酬” 的理念, 在全体教师中树立教研培训意识, 鼓励教师不断提高自身的业 务素质及业务能力, 使教师更加注重义务教育的内涵发展, 真正实现教育质 量与教学水平 “双提高” 的目标, 并以此促进广大中小学生的全面发展。

3.3 健全相关的法律法规, 保障义务教育的均衡发展。2002年, 美国联
邦政府通过了 “不让一个孩子落伍” 的 (NCLB) 法案, 旨在进一步从法律上 保障义务教育的均衡发展。我国作为一个发展中大国, 更应该完善法制建 设, 确保每个中小学生能够公平公正地获得优质义务教育资源。为此, 应加 大新《义务教育法》在领导干部、广大人民群众中的宣传力度, 让社会各 阶层深入了解义务教育均衡发展的重要性。同时, 在建设幸福黑龙江、构 建和谐社会目标的指导下, 深入各区域开展调查研究, 听取有关法律专家 的意见, 建立健全有关义务教育均衡发展的法律法规, 使义务教育均衡发 展有法可依。

\section{[参考文献]}

[1]单丹. 黑龙江省城乡义务教育公平促进机制研究 [D]. 哈尔滨师范大 学,2019(07):67.

[2]奕春晓. 黑龙江省城乡义务教育政策均衡发展分析 [J]. 商业经 济,2019(01):22-23.

[3]黑龙江省大力推进县域内义务教育均衡发展[J].新课程研究(上旬 刊),2017(05): $72+113$.

[4]张婷婷. 黑龙江省城乡义务教育均等化问题研究 [D]. 东北农业大 学,2014(01):60.

作者简介:

高红丽(1979--), 女, 汉, 黑龙江省龙江县人, 中学一级教师, 研究生, 研究方向: 教育政策。 